\title{
High resolution profiling of $X$ chromosomal aberrations by array comparative genomic hybridisation
}

\author{
J A Veltman, H G Yntema, D Lugtenberg, H Arts, S Briault, E H L P G Huys, K Osoegawa, \\ P de Jong, H G Brunner, A Geurts van Kessel, H van Bokhoven, E F P M Schoenmakers
}

J Med Genet 2004;41:425-432. doi: 10.1136/jmg.2004.018531

$T^{t}$ he causes of mental handicap are highly variable and involve both genetic and environmental factors. Approximately half of the cases have a familial origin and in $50 \%$ of these the genetic defect can be linked to the $\mathrm{X}$ chromosome. ${ }^{1}$ This group of $\mathrm{X}$ linked mental retardation patients comprises patients in whom the mental handicap is associated with other clinical features (syndromic or specific mental retardation), and patients in whom the mental deficit is the only consistent clinical or morphogenetic manifestation (non-specific mental retardation, MRX). So far, the molecular basis of MRX is poorly understood because of the extreme genetic heterogeneity of this disorder. Fourteen MRX genes have been identified over the last few years, but each of these account for only a minor fraction of all cases. Since the causative mutation has been identified in only approximately $17 \%$ of families, ${ }^{2}$ it can be estimated that up to 100 MRX genes exist. Most of the currently known MRX genes were identified through the study of microscopically visible $\mathrm{X}$ chromosomal abnormalities: OPHN1, TM4SF2, $A R H G E F 6$, and ZNF41 by positional cloning of chromosomal translocation breakpoints, ${ }^{3-6}$ and FMR2, ILIRAPL1, and FACL4 by chromosome deletion mapping. ${ }^{7-9}$ In addition, disease related genomic deletions have been identified in other MRX genes and in genes associated with numerous other $\mathrm{X}$ linked conditions.

In our laboratory, four $\mathrm{X}$ chromosomal genes associated with a human disorder have been identified based on deletion mapping: $R E P-1$ in choroideremia, ${ }^{10} N D P$ in Norrie disease, ${ }^{11}$ POU3F4 in deafness type $3,{ }^{12}$ and RPS6KA6 in mental retardation. ${ }^{13}$ Deletion mapping, however, is a time consuming method, and standard cytogenetic techniques have a limited resolution of approximately 5-10 Mb. It is a common belief that a number of deletions remain below the detection limit of these current technologies. Hence, there is a strong need for a more sensitive and comprehensive assay for the identification of additional MRX genes. Array based comparative genomic hybridisation (array $\mathrm{CGH}$ ) is highly suitable for such a comprehensive screening of the X chromosome. ${ }^{14-18}$ Here we report the construction of a full coverage $X$ chromosomal array, consisting of 1513 clones covering the entire $\mathrm{X}$ chromosome. The applicability of this array in detecting copy number changes on the $X$ chromosome (0-1-2-3 copies) was tested by hybridising total genomic DNA from nine patients with known $\mathrm{X}$ chromosomal rearrangements. All previously identified microscopic and submicroscopic X chromosomal aberrations were confirmed by our array. In addition, in three patients a previously unidentified deletion or duplication was identified. From these results we conclude that array CGH can be used efficiently to screen an entire chromosome for the presence of deletions and duplications that cannot be detected by standard cytogenetic analysis.

\section{Key points}

- Up to $25 \%$ of mental retardation in males is due to defects on the $\mathrm{X}$ chromosome. Physical characterisation of cytogenetically visible $X$ chromosomal aberrations has led to the identification of seven genes for nonspecific X linked mental retardation (MRX) to date. In addition to cytogenetically visible $X$ chromosomal rearrangements, novel methods may identify more subtle submicroscopic deletions in patients with MRX. Identification of such anomalies will immediately suggest novel candidate genes for MRX.

- We have constructed, validated, and applied a full coverage chromosome X BAC array for array based comparative genomic hybridisation (array CGH). Known single copy number changes could be detected reliably on this array, with genomic sizes of the abnormalities ranging between 0.2 and $9.2 \mathrm{Mb}$. Interestingly, three previously characterised X chromosomal inversions included in this study were all shown to contain hidden submicroscopic copy number alterations at both ends of the inversion.

- These findings exemplify the power of this high resolution copy number screening in the search for MRX genes, and illustrate that genomic rearrangements such as inversions can be associated with gain or loss of genomic material.

\section{SUBJECTS AND METHODS \\ Patients}

Genomic DNA, isolated from blood lymphocytes of four cytogenetically normal, healthy individuals (two men and two women), was used for array validation and as normal reference DNA. Additional genomic DNA was isolated from nine patients with known copy number changes on the $\mathrm{X}$ chromosome (table 1). Genomic DNA from patients and controls was isolated according to standard procedures, and was purified using a QIAamp kit (QIAgen, Valencia, CA) according to the manufacturer's instructions.

\section{Array preparation}

Genomic target DNA was isolated from deep well bacterial cultures using AutogenPrep 960 (Autogen, Holliston, MA),

Abbreviations: array $\mathrm{CGH}$, array based comparative genomic hybridisation; DFN3, X linked deafness type 3; DOP-PCR, degenerate oligonucleotide primed PCR; MRX, non-specific X linked mental retardation 
following the manufacturer's instructions. Degenerate oligonucleotide primed (DOP) PCR was performed on 50 ng DNA from all clones essentially as described before ${ }^{26}$ with minor modifications. ${ }^{16}$ Taq2000 (Stratagene, La Jolla, CA) was used as a thermostable polymerase. DOP-PCR products were dissolved at a concentration of $1 \mu \mathrm{g} / \mu \mathrm{l}$ in a $30 \%$ DMSO solution and robotically spotted in triplicate onto CMT-GAPS coated glass slides (Ultragaps, Corning, Schiphol-Rijk, The Netherlands) using an Omnigrid 100 arrayer (Genomic Solutions, Cambridgeshire, United Kingdom). The array consisted of 48 subgrids and replicates were printed in different subgrids across the array.

\section{Labelling and hybridisation}

Labelling and hybridisation were performed essentially as described before, ${ }^{16}$ with modifications. ${ }^{18}$ In brief, genomic DNA was labelled by random priming with Cy3-dUTP or Cy5dUTP (Amersham Biosciences, Uppsala, Sweden). Test and reference samples were mixed with $120 \mu \mathrm{g}$ Cot-1 DNA (Roche, Basel, Switzerland), coprecipitated and resuspended in $130 \mu \mathrm{l}$ of a hybridisation solution containing $50 \%$ formamide, $10 \%$ dextran sulphate, $2 \times$ SCC, $4 \%$ SDS and $10 \mu \mathrm{g} / \mu \mathrm{l}$ yeast tRNA (Invitrogen, Carlsbad, CA). After denaturation of probe and target DNA, hybridisation and posthybridisation washing procedures were performed using a GeneTac hybridisation station (Genomic Solutions) according to the manufacturer. In brief, an 18 hour hybridisation with active circulation of the probe was performed followed by 5 posthybridisation wash cycles in $50 \%$ formamide $/ 2 \times$ SSC at $45^{\circ} \mathrm{C}$ and 5 wash cycles in phosphate buffered saline at $20^{\circ} \mathrm{C}$. Slides were dried by centrifugation after a brief wash in water.

\section{Image analysis and processing}

Slides were scanned and imaged on an Affymetrix 428 scanner (Affymetrix, Santa Clara, CA) using the Affymetrix 428 scanner software package (version 1.0). The acquired micro-array images were analysed using Genepix Pro 4.0 (Axon Instruments, Inc., Foster City, CA) as described previously. ${ }^{16}$ For all calculations we used for each spot per dye the median of the pixel intensities minus the median local background. Data normalisation was performed using the software package SAS version 8.0 (SAS Institute, Cary, NC) per array subgrid by applying lowess curve fitting with a smoothing factor of 0.1 to predict the $\log _{2}$ transformed test over reference $(T / R)$ value on the basis of the average logarithmic fluorescent intensities as described before. ${ }^{18} 27$

\section{Quality control}

Clones with a standard deviation $>0.3$ were excluded in individual experiments, as well as clones with less than two replicates remaining after this analysis. A total of 47 clones were excluded from all experiments because these clones did not show reliable hybridisation results in at least four of the six normal versus normal control experiments. Based on the control experiments and on previously published work, thresholds for copy number, gain, and loss were set at $\log _{2} \mathrm{~T} / \mathrm{R}$ values of 0.3 and -0.3 , respectively. The replicate dye swap analysis was performed as recently described. ${ }^{18}$

\section{Validation experiments}

To verify the Xq13 deletion that was detected by array CGH, a PCR was performed using primer sets amplifying the following STS markers: DJ466I8B, RH99071, AFMI47XD12, and SHGC-148317 (primer sequences available upon request). All PCRs were performed in a PTC-200 Peltier thermal controller (Biozym, Landgraaf, The Netherlands), with cycling conditions of $95^{\circ} \mathrm{C}$ for $30 \mathrm{~s}, 60^{\circ} \mathrm{C}$ for $30 \mathrm{~s}$, and $72^{\circ} \mathrm{C}$ for $42 \mathrm{~s}$, for 35 cycles.

To verify the duplication on Xq21, a southern blot containing genomic DNA of patient 8 and an unaffected control individual ${ }^{24}$ was hybridised with radioactively labelled PCR products of the STS markers SHGC-14555 and SHGC85605, according to standard procedures.

\section{RESULTS}

\section{Development of a full coverage $\mathrm{X}$ chromosomal BAC} array

Recently, a minimum tiling path BAC set covering over $99 \%$ of the sequenced human genome was established. ${ }^{28}$ Information on this clone set and its availability can be obtained at the BACPAC Resources Center website (www.chori.org/bacpac/). From this set we selected 1513 BAC clones that had been mapped to the $\mathrm{X}$ chromosome. This set encompasses a total of $313 \mathrm{Mb}$ of chromosome $\mathrm{X}$ sequences, thereby covering the chromosome more than twice (chromosome $\mathrm{X}$ is $149.2 \mathrm{Mb}$ in size). However, there are still some gaps between clones. The largest gap is an estimated 3.1 Mb and is part of the centromeric region of the chromosome. None of the other gaps is larger than $200 \mathrm{~kb}$ (average size: $33 \mathrm{~kb}$ ). A similar full tiling set of 370 human

Table 1 Patients, reasons for referral, karyotypes, array CGH results, and comparison with the original results

\begin{tabular}{|c|c|c|c|}
\hline Patient & Reason for referral & Original results & Array $\mathrm{CGH}$ results \\
\hline 1 & $\begin{array}{l}\text { short stature, mental retardation, steroid } \\
\text { sulphatase deficiency }\end{array}$ & karyotype: $46, \mathrm{XY}$, del(X)(pterp22.31) $)^{19}$ & del 65 clones $(\approx 6 \mathrm{Mb})$ on Xpter-Xp22.31 \\
\hline 2 & $\begin{array}{l}\text { short stature, brachycephaly, frontal bossing, } \\
\text { hypertelorism, ventricular septal defect }\end{array}$ & $\begin{array}{l}\text { karyotype: } 46, X Y, \mathrm{t}(\mathrm{X} ; \mathrm{Y})(\mathrm{p} 22.3 ; q 11.2), \\
\text { del(X)(pterp22.3) } \\
\text { (T Kleefstra, personal communication) }\end{array}$ & del 32 clones $(\approx 2.5 \mathrm{Mb})$ on Xpter-Xp22.33 \\
\hline 3 & $\begin{array}{l}\text { X linked mixed deafness, choroideremia, } \\
\text { mental retardation }\end{array}$ & $\begin{array}{l}\text { karyotype: } 46, \mathrm{XY}, \operatorname{del}(\mathrm{Xq} 21), \approx 4 \mathrm{Mb} \text { deletion } \\
\mathrm{Xq}^{2} 2^{20}\end{array}$ & del 43 clones $(\approx 3.8 \mathrm{Mb})$ on $\mathrm{Xq}_{\mathrm{q} 21.1-\mathrm{Xq} 21.31}$ \\
\hline 4 & $\begin{array}{l}\text { mother of patient with moderate mental } \\
\text { retardation, hypogonadism, borderline thyroid } \\
\text { function, behavioral problems }\end{array}$ & $\begin{array}{l}\text { karyotype: } 46, X X \text {, dup }(X)(q 26 q 27) \\
\text { (C Gardiner, personal communication) }\end{array}$ & dup 97 clones $(\approx 9.2 \mathrm{Mb})$ on $\mathrm{Xq} 26.3-\mathrm{Xq}_{\mathrm{q}} 7.3$ \\
\hline 5 & Norrie disease & karyotype: $46, X Y, 150 \mathrm{~kb}$ deletion $X p 11.3^{21}$ & del 2 clones $(\approx 250 \mathrm{~kb})$ in Xp1 1.3 \\
\hline 6 & Pelizaeus-Merzbacher disease & $\begin{array}{l}\text { karyotype: } 46, \mathrm{XY} \text {, duplication PLP1 gene } \\
\text { (E Sistermans, personal communication) }\end{array}$ & dup 3 clones $(\approx 680 \mathrm{~kb})$ in $X_{q} 22$ \\
\hline 7 & $\mathrm{X}$ linked mixed deafness & $\begin{array}{l}\text { karyotype: } 46, X Y, \text { inv }(X)(q 13.1 \mathrm{q} 21.2) \text {, } \\
700 \mathrm{~kb} \text { deletion } X \mathrm{Xq}^{20}{ }^{22} 23\end{array}$ & $\begin{array}{l}\text { del } 2 \text { clones }(\approx 260 \mathrm{~kb}) \text { in } X q 13 \text {; } \\
\text { del } 4 \text { clones }(\approx 840 \mathrm{~kb}) \text { in } X q 21\end{array}$ \\
\hline 8 & $\mathrm{X}$ linked mixed deafness & $\begin{array}{l}\text { karyotype: } 46, \mathrm{XY}, \operatorname{inv}(\mathrm{X})(\mathrm{q} 21.1 \mathrm{q} 21.3) \text {, } \\
150 \mathrm{~kb} \text { duplication } \mathrm{Xq} 21.1^{24}\end{array}$ & $\begin{array}{l}\text { dup } 2 \text { clones }(\approx 265 \mathrm{~kb}) \text { in } \mathrm{Xq21.1} \text {; } \\
\text { dup } 4 \text { clones }(\approx 240 \mathrm{~kb}) \text { in } \mathrm{Xq} 21.3\end{array}$ \\
\hline 9 & FG syndrome & karyotype: $46, X Y, \operatorname{inv}(X)(q 11 q 28)^{25}$ & $\begin{array}{l}\text { dup } 2 \text { clones }(\approx 360 \mathrm{~kb}) \text { in } \mathrm{Xq1} 1 \text {; } \\
\text { dup } 4 \text { clones }(\approx 230 \mathrm{~kb}) \text { in } \mathrm{Xq} 28\end{array}$ \\
\hline
\end{tabular}


chromosome 22 clones was added to the X chromosome clones for normalisation procedures. Genomic DNA from all clones was amplified by degenerate oligonucleotide primed PCR and spotted in triplicate onto aminosilane coated glass slides as described before. ${ }^{18}$

\section{Validation of the $\mathrm{X}$ chromosomal BAC array}

To test the specificity of the $\mathrm{X}$ chromosomal BAC array we performed a series of six normal versus normal control hybridisations using DNA from four normal healthy blood donors. Replicate experiments (including a dye swap) were performed and the mean intensity ratio was calculated for each clone. Fig 1 shows the chromosome X profiles of these validation experiments, which included self-self (male 1 versus male 1 ), sex matched (male 1 versus male 2 ), and sex mismatched experiments (female versus male). In the selfself experiment all clones have $\log _{2}$ intensity ratios in between the a priori set thresholds for copy number gain $(0.3)$ or loss $(-0.3)$ (fig lA). The sex match experiment also showed a straight chromosome X profile, except for five small genomic intervals represented by a total of 10 clones that indicated a copy number difference between the two males (fig 1B). These copy number abnormalities might reflect novel genomic polymorphisms present in the healthy population. In contrast, the chromosome $X$ profile of the sex mismatched experiment showed considerable variation of the male over female intensity ratios, irrespective of the normalisation procedure (fig $\mathrm{IC}$, using the chromosome $\mathrm{X}$ clones, or fig 1D, using chromosome 22 clones). In fig $1 \mathrm{D}$, clones located in the known pseudo-autosomal regions on Xpter, Xq21, and Xqter showed intensity ratios with $\log _{2}$ ratios around 0 , as expected, whereas the $\log _{2}$ ratios of clones located in the other chromosome $\mathrm{X}$ regions varied around -0.44 (standard deviation 0.18 ).

In conclusion, sex matched hybridisations show less variation in intensity ratios over the $\mathrm{X}$ chromosome as compared with sex mismatched hybridisation profiles. From these data we conclude that screening of patients for the presence of copy number abnormalities on one of the sex chromosomes can best be performed using sex matched control DNA. The 10 clones, which reproducibly showed copy number differences in the male versus male control hybridisations, were excluded from further analysis.

\section{Analysis of patients with $\mathrm{X}$ linked disorders}

Nine patients with previously identified copy number changes affecting the $\mathrm{X}$ chromosome were hybridised against sex matched controls (table 1). This set of patients was selected on the basis of single copy number changes (deletions as well as duplications) with varying genomic sizes randomly located over the entire chromosome in both male and female patients. Patients $1-4$ had a cytogenetically visible deletion or duplication, whereas patients 5-9 were known to have submicroscopic deletions or duplications.

Figs $1 \mathrm{E}-\mathrm{H}$ show chromosome $\mathrm{X}$ profiles from the four patients with genomic abnormalities that were previously cytogenetically identified and characterised. In all cases genomic imbalances were readily identified on the chromosome $\mathrm{X}$ array and the boundaries of the deletions as well as the duplication could be determined in detail. A $6 \mathrm{Mb}$ deletion in Xpter, represented by 65 clones on our array, was detected in patient 1 , a man with $\operatorname{del}(X)($ pterp22.31). In patient 2, who had a $t(X ; Y)(\operatorname{pter} ; Y), \operatorname{del}(X)($ pterp22.3), we detected an Xpter deletion of 32 clones (spanning $2.5 \mathrm{Mb}$ ). The Xq2 1 deletion in case 3 was confirmed by array CGH and included a contiguous stretch of 43 clones encompassing a genomic interval of $3.8 \mathrm{Mb}$. The Xq26 duplication in case 4 was defined by 97 clones, encompassing a region of $9.2 \mathrm{Mb}$.
Also, a number of cases with known submicroscopic copy number changes were hybridised onto the array (patients 5-9, table 1 and fig 2). These cases were used to test the resolution of the approach for detecting copy number changes in the $\mathrm{X}$ chromosome. Fig $2 \mathrm{~A}$ shows the chromosome $\mathrm{X}$ profile of patient 5 , who harbours a deletion targeting the Norrie disease gene $N D P$ at Xpl1.3. An expanded profile of the affected region is depicted in fig $2 \mathrm{~B}$. The deletion was represented on the array by three clones mapping within a $250 \mathrm{~kb}$ interval on Xpll.3 encompassing NDP, of which two clones are well below the threshold for copy number loss. In patient 6, who was diagnosed with Pelizaeus-Merzbacher disease, a previously observed duplication of the PLP gene was confirmed by three clones on the array with a $\log _{2} \mathrm{~T} / \mathrm{R}$ value $>0.3$, all mapping within a $680 \mathrm{~kb}$ interval on Xq22 encompassing PLP (figs $2 \mathrm{C}$ and D).

The added value of array based CGH for the detection of novel $\mathrm{X}$ chromosomal aberrations was perhaps best illustrated in the experiments with DNA derived from three inversion patients (patients 7-9) (figs 2E-M). Figs 2E-G show the chromosome $X$ profiles of a male patient who was reported to carry an inversion X(q13q21) accompanied by a deletion of $700 \mathrm{~kb}$ at Xq21 (patient 7). ${ }^{23}$ This deletion was characterised by four overlapping BAC clones on the array $(\approx 840 \mathrm{~kb}$, fig $2 \mathrm{G})$. Interestingly, the chromosome $X$ profile of this patient revealed a copy number deletion in two clones on $\mathrm{Xq13}$ as well (figs $2 \mathrm{E}$ and F). These two clones represent a genomic interval of approximately $260 \mathrm{~Kb}$. The absence of these two clones in the DNA of this patient was confirmed using PCR of STS markers in the region (fig 3A). This finding leads to the conclusion that the inversion is accompanied by a deletion at both inversion breakpoints. Patient 8 was known to have, next to an inversion $\operatorname{inv}(X)(\mathrm{q} 21.1 \mathrm{q} 21.3)$, a duplication of $150 \mathrm{~kb}$ involving the POU3F4 gene on Xq21.1. ${ }^{24}$ The size of this duplication as determined by array CGH corresponds well with the original results, and was shown to affect two overlapping BAC clones (figs $2 \mathrm{H}$ and I). An additional, as yet unknown, duplication of approximately $240 \mathrm{~kb}$ was identified in Xq21.3 (fig 2J). Verification of these results was performed by semiquantitative Southern blot analysis with the patient DNA and a probe in the region (fig 3B). Like the first inversion case, this result indicates that the inversion was not only accompanied by a submicroscopic duplication on Xq21.1 but also by an additional one on $\mathrm{Xq} 21.3$.

A third $X$ chromosomal inversion patient $\operatorname{inv}(X)(q 11 q 28)$ hybridised on the $\mathrm{X}$ array was diagnosed with FG syndrome. ${ }^{25}$ Besides the cytogenetically visible inversion, we recently identified a submicroscopic duplication in the breakpoint region on Xq28 (data not shown). The presence of this Xq28 duplication was confirmed on the $\mathrm{X}$ array and measures approximately $230 \mathrm{~kb}$ (four clones, figs $2 \mathrm{~K}$ and $\mathrm{M}$ ). In addition, the chromosome $\mathrm{X}$ array again identified a previously unidentified copy number alteration at the other end of the inversion. This time a $360 \mathrm{~kb}$ duplication was detected by two clones on Xq11 (fig 2L).

In conclusion, the sensitivity to detect submicroscopic deletions and duplications was reproducibly validated on the chromosome X BAC array and three novel aberrations (one microdeletion and two microduplications) were identified using this array based approach in patients with inversions.

\section{DISCUSSION}

In this study we demonstrate the applicability of an array based technology, capable of screening the entire human $\mathrm{X}$ chromosome for copy number alterations in a single hybridisation reaction. The clones used as targets on this array were selected on basis of fingerprint maps to represent 

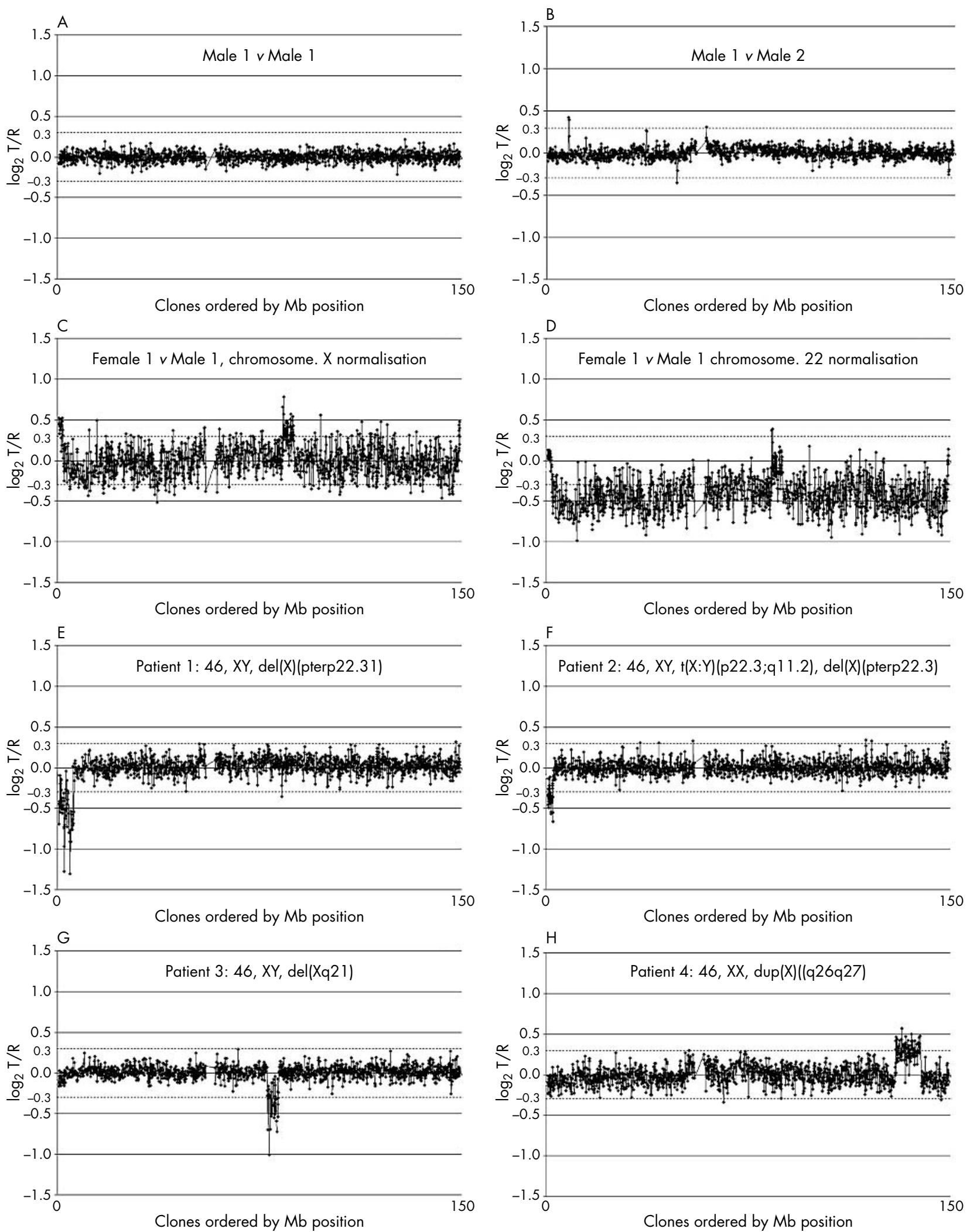

Figure 1 Validation of the full coverage chromosome $X$ array, showing chromosome $X$ array CGH profiles of the entire array, which contains 1513 human chromosome $\mathrm{X}$ clones. The $\mathrm{x}$ axis displays the $\mathrm{Mb}$ position of the clones on the $\mathrm{X}$ chromosome, ordered from Xpter to Xgter on the basis of the genomic position (see www.bcgsc.ca/lab/mapping/bacrearray/human/). Each dot represents the mean $\log _{2}$ transformed and lowess normalised test over reference intensity ratio for each clone (y axis), which is derived from three independent replica spots on the array, in a replicate dye swap

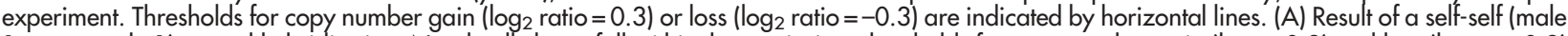
1 versus male 1) control hybridisation. Nearly all clones fall within the a priori set thresholds for copy number gain $\left(\log _{2}=0.3\right)$ and $\operatorname{loss}_{(}\left(\log _{2}=-0.3\right.$ indicated by the horizontal lines. (B) Result of sex matched (male 1 versus male 2) control experiment, showing five small genomic intervals with a copy number difference between the two males (10 clones). ( $C$ and $D$ ) Results of sex mismatched experiments (female 1 versus male 1). (C) profile using 
a minimal tiling path over the entire chromosome (see www.bcgsc.ca/lab/mapping/bacrearray/human/). ${ }^{28}$ On average, this array contains 1 clone per $99 \mathrm{~kb}$, with an average clone size of $200 \mathrm{~kb}$, resulting in a more than twofold coverage of chromosome $\mathrm{X}$. This resolution is comparable to that of the recently reported chromosome 22 array. ${ }^{29}$ The study presented here clearly demonstrates the potential of this array in the search of submicroscopic copy number alterations in regions harbouring candidate genes for $\mathrm{X}$ linked diseases such as XLMR.

To test the specificity of the chromosome X BAC array, a series of normal versus normal control hybridisations was performed. Dye swap replicate analyses turned out to be essential to minimise the percentage of false positive results, as our group recently described for genome wide copy number screening by array $\mathrm{CGH}^{18}{ }^{18}$ Despite these replicate analyses, a high degree of variability in intensity ratios was observed in the sex mismatched hybridisations. This variation can be attributed to varying percentages of homology of the $\mathrm{X}$ chromosome to the autosomes and to the Y chromosome. As an example, the pseudo-autosomal region on Xq21 shows relatively low female to male ratios (figs $1 C$ and D). In contrast, no such variability was observed in self versus self experiments and the sex matched experiments. Therefore, we decided to perform sex matched patient versus control experiments in the remainder of the study. Interestingly, reproducible copy number differences were observed for 10 chromosome X clones in hybridisations of one male control versus another male control but not in self versus self hybridisations. These abnormalities must be studied in more detail and on more control samples before any conclusion can be drawn, but they could well represent novel genomic polymorphisms. Frequent genomic polymorphisms were recently also identified on our $1 \mathrm{Mb}$ genome wide array. ${ }^{18}$

The performance of the full coverage $\mathrm{X}$ array was validated in a series of nine patients with variably sized single copy number deletions and duplications on the X chromosome. In all cases the genomic abnormality could easily be identified in a replicate experiment without prior knowledge regarding the genomic region involved and with a minimum of false positive results $(0-3$ false positive clones per case in this study, see figs 1 and 2). Our data show that the number of false negatives is also minimal, although occasionally a clone within an affected region fails to reach the threshold for either copy number gain or loss. The genomic boundaries of the abnormalities could be precisely mapped down to a single clone resolution, allowing an immediate identification of the genes affected. As an example, patient 5 showed a deletion in three adjacent clones on Xpl1.3 representing a genomic sequence of approximately $250 \mathrm{~kb}$. Analysis of this genomic region on the UCSC genome browser revealed that the NDP gene, the $M A O-B$ gene and part of the $M A O-A$ gene are located within the deletion interval. The initial identification and delineation of the deletion in this Norrie disease patient took several years, ${ }^{21}{ }^{30}$ whereas this array based screening was performed and analysed within a week. The previous results obtained in this patient provide further insight into the performance of our BAC array. Exon 6 of the $M A O-B$ gene was previously shown to be present in this patient. ${ }^{21}$ This exon is located within clone RP11-72J03 which clearly showed an intensity ratio below the threshold for copy number loss on our array. We calculated that $81 \mathrm{~kb}$ of BAC clone RP11-72J03 (with a total size of $150 \mathrm{~kb}$ ) is absent; indicating that only half of the clone needs to be deleted for detection by this approach.

Interestingly, the array based chromosome $\mathrm{X}$ profile of three patients with an inversion on the $\mathrm{X}$ chromosome revealed previously unidentified submicroscopic copy number alterations in all three patients. All of these could be confirmed by an independent method. In a patient (patient 7) with an $\operatorname{inv}(X)(q 13 q 21)$ a previously identified $700 \mathrm{~kb}$ deletion in $\mathrm{Xq}_{2} \mathrm{l}^{23}$ was confirmed by array $\mathrm{CGH}$. To our surprise, we detected a second deletion of $260 \mathrm{~kb}$ at Xq13. The phenotype of the patient was reported to be $X$ linked deafness type 3 (DFN3: MIM304400), which was previously explained by the deletion upstream of the POU3F4 gene in $\mathrm{Xq} 21 .{ }^{22}$ Since no additional phenotypic features were noted in the patient ( $\mathrm{N}$ Dennis, personal communication), at present no firm conclusions on the pathogenicity of the deletion in Xq13 can be drawn. The second patient (patient 8) with an inversion $\operatorname{inv}(X)(q 21.1 \mathrm{q} 21.3)$ was described to have a duplication of $150 \mathrm{~kb}$, upstream of the POU $3 F 4$ gene that causes the DFN3 phenotype. ${ }^{24}$ Also in this case, an additional duplication (approximately $240 \mathrm{~kb}$ ) was found at Xq21.3. These results indicate that the PCDHIIX gene must be partially duplicated in this patient. The gene encodes a member of the protocadherin superfamily, is expressed predominantly in the brain, and has a homologue on the Y chromosome. ${ }^{31}$ Although the duplication of this gene is interesting, retrospectively, no additional phenotypic features besides DFN3 could be identified in this patient (M Reardon, personal communication). The third inversion, $\operatorname{inv}(X)(q 11 q 28)$, was found in a patient with FG syndrome (patient 9, MIM300321). ${ }^{25}$ This inversion is accompanied by a recently identified submicroscopic duplication in Xq28. Through array $\mathrm{CGH}$ this duplication could not only be confirmed but also revealed its approximately genomic size of $230 \mathrm{~kb}$. This duplication was represented by five clones on the array and encompasses five mapped genes on Xq28: OPNILW, CXorf2, TKTL1, FLNA, and EMD. Surprisingly, the chromosome $X$ profile of this patient also shows an additional duplication at the other inversion breakpoint. Two clones in Xqll were found to be duplicated. Previous fluorescent in situ hybridisation analysis with YAC ICI24AHIO indicated that this clone was spanning the inversion breakpoint in Xq11, ${ }^{25}$ since two split signals (on Xq11 and Xq28) were found. From our array CGH data we conclude that a duplication event must have preceded the inversion, explaining the double FISH signal. As yet, the duplicated region on Xql 1 contains no annotated genes.

The three novel submicroscopic copy number changes identified on this full coverage chromosome $X$ array demonstrate the power of the array CGH approach. While microscopically visible deletions often lead to $X$ linked contiguous gene mental retardation syndromes, it is expected that smaller deletions may result in less severe phenotypes such as non-specific $X$ linked mental retardation (MRX). Therefore, we will use this array to screen a large panel of men with MRX, to identify novel target genes associated with $\mathrm{X}$ linked mental retardation. Furthermore, array CGH may be used as a routine diagnostic test for the identification of $\mathrm{X}$ chromosomal aberrations. However, we caution that it will be necessary to validate this approach in a large series of control samples in order to identify and characterise submicroscopic genomic polymorphisms. Such polymorphisms may involve

1513 chromosome X clones for data normalisation. (D) Profile using 370 chromosome 22 clones for data normalisation. (E-H) Chromosome X profiles of four patients with relatively large copy number changes. (E) Normalised average ratio from hybridisation of normal male versus DNA of a male patient with an Xpter deletion (patient 1). (F) Partial loss of Xpter in genomic DNA from male patient 2. (G) Deletion of most of Xq21 including the POU3F4 gene in male patient 3. (H) Duplication of Xq26-Xq27 in female patient 4. The array based chromosome X profile allows an immediate identification and precise mapping of the genomic region involved in all four patients. 

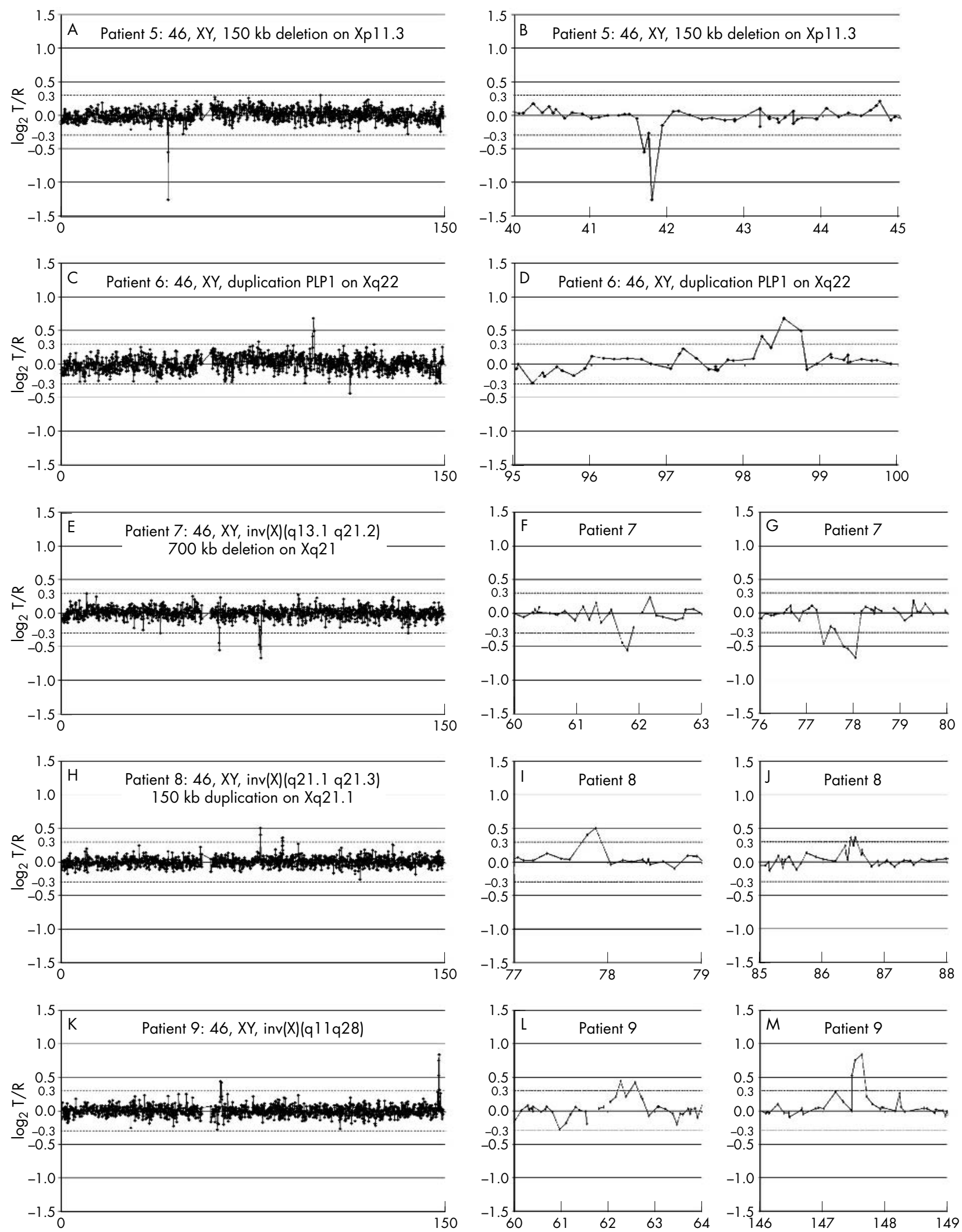

Clones ordered by Mb position
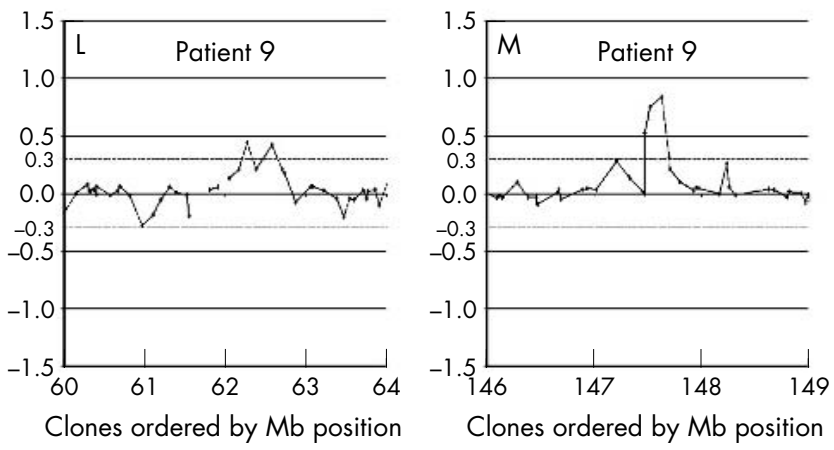

Figure 2 Detection of submicroscopic chromosome X copy number abnormalities. See fig 1 for details on the construction of this figure. (A and B) Overview and detailed view of Xp1 1.3 deletion of three clones encompassing the Norrie disease gene NDP (patient 5). (C and D) Overview and detailed view of a duplication of four clones encompassing the PLP1 gene in Xq22 (patient 6). (E) Overview of chromosome $X$ profile from a man with an $\operatorname{inv}(X)(q 13.1 q 21.2)$ (patient 7). (F and G) Enlarged, detailed views of the deletion in Xq13.1 and Xq21.2, which are derived from the experiment shown in panel (E). (H-J) Overview and detailed views of the hybridisation of DNA of patient 8 versus a normal male control. Two duplications are present associated with the inversion breakpoints $(\mathrm{K}-\mathrm{M})$ Overview of the chromosome $\mathrm{X}$ profile and detailed views of the duplication in Xq11 and Xq28, respectively (patient 9). 

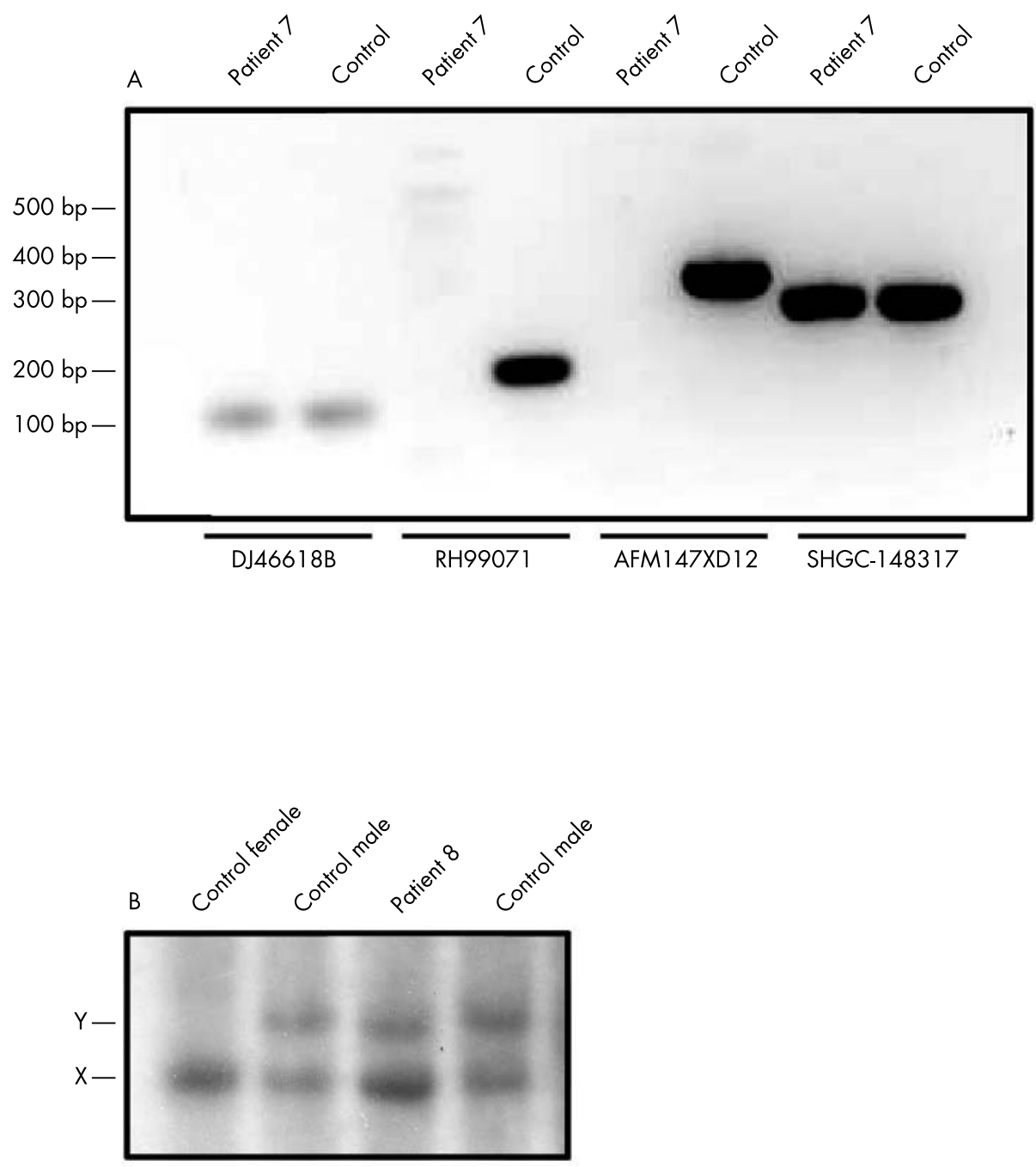

Figure 3 Validation of novel findings on the X array. (A) PCR amplification of four STS markers in Xq13. Markers DJ66618B and SHGC-148317 are present in the DNA of patient 7. Two markers located on clones that were found to be deleted by array CGH, RH99071 and AFM147XD12, are indeed absent in the patient's DNA. (B) Southern blot hybridisation. EcoR1 digested DNA of controls and patient 8 was hybridised with a PCR product obtained from marker SHGC-14555. Since the probe is located in the pseudoautosomal region, two hybridisation signals are present in the male subjects. The upper band represents a signal on the $\mathrm{Y}$ chromosome; the lower represents the signal specific to the $\mathrm{X}$ chromosome. The intensity of the band in the patient is the same as in the control female, indicating that the $X$ chromosomal segment is duplicated. Furthermore, the male controls show equal intensity on the $\mathrm{X}$ and the $\mathrm{Y}$ chromosomal bands, whereas the intensity of the $\mathrm{X}$ chromosomal signal in patient 8 is twice as strong.

deletions or duplications of up to several hundred kilobases without any apparent phenotypic effect.

\section{ACKNOWLEDGEMENTS}

We thank E Sistermans, T Kleefstra, B de Vries, C A Gardiner, D Robinson, and N Dennis for providing DNA samples and clinical information on patients with $\mathrm{X}$ chromosomal rearrangements. We would also like to thank W van der Vliet, T Feuth, and C on Choy for expert technical assistance.

\section{Authors' affiliations}

J A Veltman*, H G Yntema*, D Lugtenberg, H Arts, E H L P G Huys, H G Brunner, A Geurts van Kessel, H van Bokhoven,

E F P M Schoenmakers, Department of Human Genetics, University Medical Centre Nijmegen, Nijmegen, The Netherlands

S Briault, Service de Génétique et INSERM U316, Hôpital Bretonneau, Tours, France

K Osoegawa, P de Jong, BACPAC resources, Oakland, CA, USA
*The first two authors should be regarded as joint first authors.

This work was supported by research grants from the European Communion (QLG3-CT-2002-01810 (EURO-MRX)), and the Brain Foundation of the Netherlands H02.10 (to H G Yntema).

Conflict of interest: none declared.

Correspondence to: J A Veltman, PhD, Department of Human Genetics (417), University Medical Centre Nijmegen, PO Box 9101, 6500 HB Nijmegen, The Netherlands; j.veltman@antrg.umcn.nl

Revised version received 25 February 2004 Accepted for publication 25 February 2004

\section{REFERENCES}

1 Hagberg B, Kyllerman M. Epidemiology of mental retardation-a Swedish survey. Brain Dev 1983;5:441-9.

2 Ropers HH, Hoeltzenbein M, Kalschever V, Yntema H, Hamel B, Fryns JP, Chelly J, Partington M, Gecz J, Moraine C. Nonsyndromic X-linked mental retardation: where are the missing mutations? Trends Genet 2003;19:316-20. 
3 Billuart $\mathbf{P}$, Bienvenu $T$, Ronce $N$, des Portes $V$, Vinet $M C$, Zemni R, Roest Crollius $H$, Carrié A, Fauchereau F, Cherry M, Briault S, Hamel B, Fryns JP, Beldjord C, Kahn A, Moraine C, Chelly J. Oligophrenin-1 encodes a rho-GAP protein involved in X-linked mental retardation. Nature 1998;392:923-6.

4 Zemni R, Bienvenu T, Vinet MC, Sefiani A, Carrié A, Billuart $P$, McDonell N Couvert $P$, Francis $F$, Chafey $P$, Fauchereau F, Friocourt $G$, des Portes $V$, Cardona A, Frints S, Meindl A, Brandau O, Ronce N, Moraine C, van Bokhoven H, Ropers HH, Sudbrak R, Kahn A, Fryns JP, Beldjord C, Chelly J. A new gene involved in $\mathrm{X}$-linked mental retardation identified by analysis of an $X ; 2$ balanced translocation. Nat Genet 2000;24:167-70.

5 Kutsche K, Yntema H, Brandt A, Jantke I, Nothwang HG, Orth U, Boavida MG David D, Chelly J, Fryns JP, Moraine C, Ropers HH, Hamel BCJ, van Bokhoven H, Gal A. Mutations in ARHGEF6, encoding a guanine nucleotide exchange factor for Rho GTPases, in patients with X-linked mental retardation. Nat Genet 2000:26:247-50

6 Shoichet SA, Hoffmann K, Menzel C, Trautmann U, Moser B, Hoeltzenbein M, Echenne B, Partington M, van Bokhoven H, Moraine C, Fryns JP, Chelly J, Rott HD, Ropers HH, Kalscheuer M. Mutations in the ZNF41 gene are associated with cognitive deficits: identification of a new candidate for X-linked mental retardation. Am J Hum Genet 2003;73:1341-54.

7 Gecz J, Gedeon AK, Sutherland GR, Mulley JC. Identification of the gene FMR2, associated with FRAXE mental retardation. Nat Genet 1996; 13:105-8.

8 Carrié A, Jun L, Bienvenu $T$, Vinet MC, McDonell N, Couvert $P$, Zemni R, Cardona A, Van Buggenhout G, Frints S, Hamel B, Moraine C, Ropers HH, Strom T, Howell GR, Whittaker A, Ross MT, Kahn A, Fryns JP, Beldjord C, Marynen P, Chelly J. A new member of the IL-1 receptor family highly expressed in hippocampus and involved in X-linked mental retardation. Nat Genet 1999:23:25-31.

9 Meloni I, Muscoletta M, Raynaud M, Longo I, Bruttini M, Moizard MP, Gomot M, Chelly J, des Portes V, Fryns JP, Ropers HH, Magi B, Bellan C, Volpi N, Yntema HG, Lewis SE, Śchaffer JE, Renieri A. FACL4, encoding fatty acid-CoA ligase 4, is mutated in nonspecific $\mathrm{X}$-linked mental retardation. Nat Genet 2002;30:436-40.

10 Cremers FPM, van de Pol DJR, van Kerkhoff LPM, Wieringa B, Ropers HH. Cloning of a gene that is rearranged in patients with choroideremia. Nature 1990;347:674-7.

11 Berger W, van de PD, Warburg M, Gal A, Bleeker-Wagemakers L, de Silva H, Meindl A, Meitinger T, Cremers F, Ropers HH. Mutations in the candidate gene for Norrie disease. Hum Mol Genet 1992;1:461-5.

12 De Kok YJM, van der Maarel SM, Bitner-Glindzicz M, Huber I, Monaco AP, Malcolm S, Pembrey ME, Ropers HH, Cremers FPM. Association between $X$-linked mixed deafness and mutations in the POU domain gene POU3F4. Science 1995;267:685-8

13 Yntema HG, van den Helm B, Kissing J, van Duijnhoven G, Poppelaars F, Chelly J, Moraine C, Fryns JP, Hamel BCJ, Heilbronner H, Pander HJ, Brunner HG, Ropers $\mathrm{HH}$, Cremers FPM, van Bokhoven $\mathrm{H}$. A novel ribosoma S6-kinase (RSK4; RPS6KA6) is commonly deleted in patients with complex X-linked mental retardation. Genomics 1999;62:332-43.

14 Pinkel D, Segraves R, Sudar D, Clark S, Poole I, Kowbel D, Collins C, Kuo WL, Chen C, Zhai Y, Dairkee SH, Ljung BM, Gray JW, Albertson DG. High resolution analysis of DNA copy number variation using comparative genomic hybridization to microarrays. Nat Genet 1998;20:207-11.

15 Solinas-Toldo S, Lampel S, Stilgenbauer S, Nickolenko J, Benner A, Dohner H, Cremer T, Lichter P. Matrix-based comparative genomic hybridization: biochips to screen for genomic imbalances. Genes Chromosomes Cancer 1997; 20:399-407.

16 Veltman JA, Schoenmakers EF, Eussen BH, Janssen I, Merkx G, van Cleef B van Ravenswaaii CM, Brunner HG, Smeets D, Geurts van Kessel A. Highthroughput analysis of subtelomeric chromosome rearrangements by use of array-based comparative genomic hybridization. Am J Hum Genet 2002;70:1269-76

17 Veltman JA, Jonkers Y, Nuijten I, Janssen I, Van der Vliet W, Huys E, Vermeesch J, Van Buggenhout G, Fryns JP, Admiraal R, Terhal P, Lacombe D,
Geurts van Kessel A, Smeets D, Schoenmakers EF, van Ravenswaaii-Arts CM. Definition of a critical region on chromosome 18 for congenital aural atresia by arrayCGH. Am J Hum Genet 2003;72:1578-84.

18 Vissers LE, de Vries BB, Osoegawa K, Janssen IM, Feuth T, Choy CO, Straatman H, Van der Vliet W, Huys EH, Van Rijk A, Smeets D, RavenswaaiiArts CM, Knoers NV, Van der Burgt I, de Jong PJ, Brunner HG, Geurts van Kessel A, Schoenmakers EF, Veltman JA. Array-based comparative genomic hybridization for the genomewide detection of submicroscopic chromosomal abnormalities. Am J Hum Genet 2003;73:1261-70.

19 De Vries BB, Eussen BH, van Diggelen OP, van Der HA, Deelen WH Govaerts LC, Lindhout D, Wouters CH, Van Hemel JO. Submicroscopic Xpter deletion in a boy with growth and mental retardation caused by a familial $t(X ; 14)$. Am J Med Genet 1999;87:189-94.

20 Huber I, Bitner-Glindzicz M, de Kok YJM van der Maarel SM IshikawaBrush Y, Monaco AP, Robinson D, Malcolm S, Pembrey ME, Brunner HG Cremers FPM, Ropers H-H. X-linked mixed deafness (DFN3): cloning and characterization of the critical region allows the identification of novel microdeletions. Hum Mol Genet 1994;3:1151-4.

21 Lenders JW, Eisenhofer G, Abeling NG, Berger W, Murphy DL, Konings CH, Wagemakers LM, Kopin IJ, Karoum F, van Gennip AH, Brunner HG. Specific genetic deficiencies of the $A$ and $B$ isoenzymes of monoamine oxidase are characterized by distinct neurochemical and clinical phenotypes. J Clin Invest 1996;97:1010-9.

22 Robinson D, Lamont M, Curtis G, Shields DC, Phelps P. A family with X-linked deafness showing linkage to the proximal $X q$ region of the $X$ chromosome. Hum Genet 1992;90:316-8.

23 De Kok YJM, Vossenaar ER, Cremers CWRJ, Dahl N, Laporte J, Hu U, Lacombe D, Fischel-Ghodsian N, Friedman RA, Parnes LS, Thorpe P, BitnerGlindzicz M, Pander H-J, Heilbronner H, Graveline J, den Dunnen JT, Brunner HG, Ropers H-H, Cremers FPM. Identification of a hot spot for microdeletions in patients with X-linked deafness type 3 (DFN3) $900 \mathrm{~kb}$ proximal to the DFN3 gene POU3F4. Hum Mol Genet 1996;5:1229-35.

24 De Kok YJM, Merkx GF, van der Maarel SM, Huber I, Malcolm S, Ropers HH, Cremers FPM. A duplication/paracentric inversion associated with familial $X$-linked deafness (DFN3) suggests the presence of a regulatory element more than $400 \mathrm{~kb}$ upstream of the POU3F4 gene. Hum Mol Genet 1995:4:2145-50

25 Briault S, Villard L, Rogner U, Coy J, Odent S, Lucas J, Passage E, Zhu D, Shrimpton A, Pembrey M, Till M, Guichet A, Dessay S, Fontes M, Poustka A, Moraine C. Mapping of $X$ chromosome inversion breakpoints [inv $(X)(q 11$ q28)] associated with FG syndrome: a second FG locus [FGS2]? Am J Med Genet 2000;95:178-81.

26 Telenius H, Carter NP, Bebb CE, Nordenskjold M, Ponder BA, Tunnacliffe A. Degenerate oligonucleotide-primed PCR: general amplification of target DNA by a single degenerate primer. Genomics 1992;13:718-25

27 Cleveland WS. Robust locally weighted regression and smoothing scatterplots. J Am Stat Assoc 1979;74:829-36.

28 Ishkanian AS, Malloff CA, Watson SK, deLeeuw RJ, Chi B, Coe BP, Snijders A, Albertson DG, Pinkel D, Marra MA, Ling V, MacAulay C, Lam WL. A tiling resolution DNA microarray with complete coverage of the human genome. Nat Genet 2004;36:299-303.

29 Buckley PG, Mantripragada KK, Benetkiewicz M, Tapia-Paez I, Diaz DS Rosenquist $M$, Ali H, Jarbo C, De Bustos C, Hirvela C, Sinder WB, Fransson I, Thyr C, Johnsson BI, Bruder CE, Menzel U, Hergersberg M, Mandahl N, Blennow E, Wedell A, Beare DM, Collins JE, Dunham I, Albertson D, Pinkel D Bastian BC, Faruqi AF, Lasken RS, Ichimura K, Collins VP, Dumanski JP. A fullcoverage, high-resolution human chromosome 22 genomic microarray for clinical and research applications. Hum Mol Genet 2002;1 1:3221-9.

30 Berger W, Meindl A, van de Pol TJ, Cremers FP, Ropers HH, Doerner C, Monaco A, Bergen AA, Lebo R, Warburg M. Isolation of a candidate gene for Norrie disease by positional cloning. Nat Genet 1992;1:199-203.

31 Blanco $P$, Sargent CA, Boucher CA, Mitchell M, Affara NA. Conservation of $\mathrm{PCDHX}$ in mammals; expression of human $X / Y$ genes predominantly in brain. Mamm Genome 2000;11:906-14. 